\title{
Pengaruh Variasi Komposisi Pada Campuran Limbah Cair Aren dan Kotoran Sapi Terhadap Produksi Biogas
}

\section{The Influence of Composition Variation on The Mixture of Aren (Arenga Pinata Merr) Liquid Waste and Cow Dung on Gas Production}

\author{
Ramdiana $^{\mathrm{a}^{*}}$ \\ ${ }^{a}$ Program Studi Teknik Lingkungan Universitas Teknologi Sulawesi, Makassar, \\ Jl. Talasalapang No.51 Makassar
}

\section{Artikel histori :}

Diterima Oktober 2017 Diterima dalam revisi November 2017 Diterima November 2017 Online Desember 201

\begin{abstract}
ABSTRAK: Limbah cair aren dan kotoran sapi merupakan substrat yang baik dalam pembuatan biogas, karena tanaman aren mengandung bahan organik yang tinggi dan kotoran sapi mengandung bakteri penghasil gas metan. Nilai rasio $\mathrm{C} / \mathrm{N}$ dari limbah cair aren yaitu 15 dan perlu dicampur dengan limbah yang memiliki rasio $\mathrm{C} / \mathrm{N}$ lebih tinggi dari kotoran sapi yaitu 24. Penelitian dilakukan dengan proses anaerobic reactor. Penelitian ini menguji 5 variasi komposisi campuran kotoran sapi dan limbah cair aren yaitu $1: 0,25,1: 0,5,1: 0.75,1$ : 1 dan 1: 1,25. Masing-masing sampel dimasukkan ke dalam digester dengan kapasitas 14 liter terdiri dari 11 liter campuran limbah dan 3 liter air, kemudian diinkubasi secara anaerob dalam ruang bersuhu antara $25^{\circ} \mathrm{C}-30^{\circ} \mathrm{C}$ selama 50 hari. Parameter yang diukur berupa volume biogas, gas metan, nilai $\mathrm{C} / \mathrm{N}$ rasio, $\mathrm{pH}$ dan suhu. Pengamatan volume gas dilakukan setiap hari dengan menggunakan gas holder dan konsentrasi gas metan diuji dengan Gas Chromatography (GC). Hasil penelitian menunjukkan bahwa komposisi campuran kotoran sapi dan limbah cair aren 1:1,25 menghasilkan biogas tertinggi dengan kadar gas metan $42 \%$.

Kata Kunci: limbah cair aren; kotoran sapi; biogas.
\end{abstract}

\begin{abstract}
Aren (Arenga Pinnata Merr) liquid waste and cow manure are good substrate for biogas production, because aren plants have high organic content and cow dung have methanogen bacteria to produce methane gas. $\mathrm{C} / \mathrm{N}$ rasio value of aren liquid waste is 15 and need to mixture another raw material with higher $\mathrm{C} / \mathrm{N}$ ratio such as cow manure is 24 . This research had been used with batch anaerobic reactor process. There are 5 variation composition of aren liquid waste and cow dung in this experiment which is $1: 0,25,1: 0,5,1$ : $0.75,1: 1$ and 1: 1,25. Every sample was filled to 14 litre capacity of digester by 11 litre of waste mixture and 3 litre of water then incubated at $25^{\circ} \mathrm{C}-30^{\circ} \mathrm{C}$ during 50 days. The parameter measured were the volume of biogas, methane gas, $\mathrm{C} / \mathrm{N}$ ratio, $\mathrm{pH}$ and temperature. Observation of gas volume using gas holder. The consentration of methan was tested using Gas Chromatography (GC). The experiment result showed that the best composition of mixture cow dung and aren liquid waste in the ratio of 1:1,25 produces the highest biogas with methane gas content $42 \%$.
\end{abstract}

Keywords: aren liquid waste; cow manure; biogas.

\section{Pendahuluan}

Biogas adalah gas yang dihasilkan dari aktivitas mikroba secara anaerobik pada bahan-bahan organik yang biodegradable. Kandungan utama yang penting dalam biogas adalah metan (55-75\%) dan karbondioksida (22$45 \%$ ). Biogas dapat berasal dari pemanfaatan kotoran hewan, sampah buah, sampah organik, limbah tahu, dan limbah lain yang dapat didegradasi. Untuk memperoleh produksi biogas yang optimal dapat dilakukan dengan pencampuran limbah organik dengan kotoran hewan sehingga parameter derajat keasamaan $(\mathrm{pH})$, rasio $\mathrm{C} / \mathrm{N}$ dapat memenuhi syarat dalam pembentukan biogas. Nilai ratio $\mathrm{C} / \mathrm{N}$ dibutuhkan dalam pembentukan biogas mencapai 20-30 dengan nilai $\mathrm{pH}$ 6,8-8,5.

Limbah cair aren diperoleh dari proses pembuatan tepung aren. Dalam proses pembuatannya, industri tepung aren menghasilkan limbah berupa limbah cair dan limbah padat berupa ampas. Lebih lanjut menurut Potter, dkk (1994) menyebutkan bahwa sebagian besar limbah cair yang dihasilkan oleh industri pembuatan tepung aren

${ }^{*}$ Corresponding Author:

Email: Ramdiana.uts@gmail.com 
adalah cairan berwarna coklat. Cairan tersebut mengandung protein yang tinggi dan dapat segera terurai. Tingginya bahan organik dalam limbah cair tepung aren termasuk kandungan amoniak menyebabkan menurunnya kandungan oksigen dalam air, sehingga kebutuhan oksigen biologi (BOD) dan kimia (COD) dalam perairan tinggi. Apabila kandungan oksigen dalam air tidak mencukupi untuk kehidupan mikroorganisme anaerob, maka proses biodegradable akan terjadi secara anaerob.

Sektor peternakan merupakan salah satu sumber pendapatan bagi masyarakat di Indonesia. Selain manfaat yang cukup besar yang dihasilkan oleh sektor peternakan ini, namun di sisi lain juga menjadi penyebab timbulnya pencemaran. Hasil lain dari ternak berupa limbah yang semakin intensif sehingga dalam sektor yang besar akan menimbulkan masalah yang lebih kompleks. Selain bau yang tidak sedap, keberadaannya juga mencemari lingkungan dan mengganggu pandangan juga dapat menjadi sumber penyakit. Disisi lain limbah peternakan berupa kotoran sapi merupakan substrat yang dianggap paling cocok sebagai sumber pembuat biogas, karena substrat tersebut telah mengandung bakteri penghasil gas metan yang terdapat dalam perut hewan ruminansia (Meynell, 1976 dalam Irwanto, 2008).

Nilai rasio $\mathrm{C} / \mathrm{N}$ dari limbah cair aren yaitu 15 sehingga perlu dicampur dengan limbah yang mempunyai rasio $\mathrm{C} / \mathrm{N}$ yang lebih tinggi yaitu kotoran sapi dengan rasio C/N 24 . Pencampuran kedua limbah tersebut dapat berpotensi untuk dimanfaatkan menjadi biogas. Keuntungan lain dari pencampuran kedua limbah tersebut dapat mengurangi penggunaan air dalam proses pembuatan biogas.

Faktor-faktor yang mempengaruhi pembentukan biogas adalah kondisi anaerob, kandungan atau senyawa dalam bahan, temperatur, derajat keasaman $(\mathrm{pH})$, ketersediaan nutrisi, pengadukan, zat racun (toxic), dan pengenceran (kadar air). Namun variasi komposisi pada pencampuran limbah juga memiliki pengaruh yang cukup besar terhadap kadar metan yang akan dihasilkan dalam pembentukan biogas. Pencampuran kedua limbah dapat mempengaruhi nilai derajat keasaman $(\mathrm{pH})$, rasio $\mathrm{C} / \mathrm{N}$ serta pengenceran (kadar air). Dalam penelitian ini dilakukan untuk mengetahui pengaruh variasi komposisi perbandingan campuran antara limbah cair aren dan kotoran sapi terhadap biogas yang dihasilkan.

\section{Metode Penelitian}

\subsection{Bahan dan Alat}

Bahan utama dalam penelitian ini terdiri dari limbah cair aren diambil di kawasan industri tepung aren dengan cara menampung cairan limbah dari proses pencucian pati aren, kotoran sapi yang diperoleh dari peternakan di KP4 UGM Yogyakarta dan air diambil pada laboratorium KEPP.

Alat penelitian berupa rangkaian reaktor anaerobik yang terdiri dari 5 digester berkapasitas 14 liter dengan masingmasing variasi campuran.

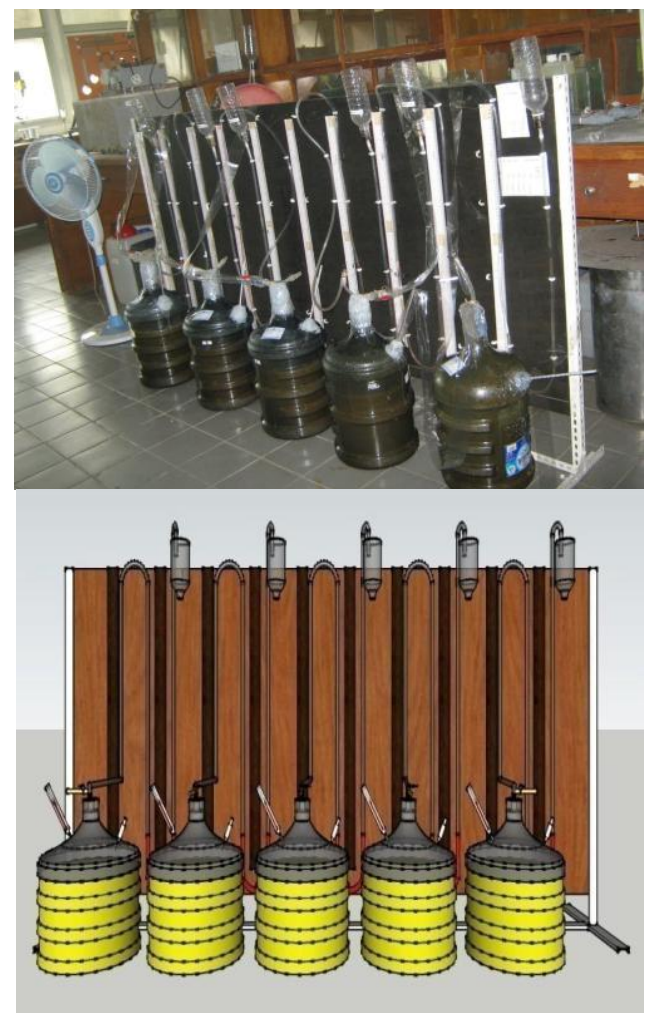

Gambar 1. Rangkaian Digester

\subsection{Prosedur Penelitian}

Pembuatan biogas dari limbah cair aren dan kotoran sapi.

1. Membuat campuran limbah cair aren dan kotoran sapi dengan komposisi pada Tabel 1 dan Tabel 2.

2. Mengencerkan campuran tersebut dengan menambah air dengan perbandingan antara kotoran : air = $1: 0,5$ (perbandingan volume)

3. Memasukan campuran ke dalam masing-masing digester

4. Melakukan perapatan dengan proses lem pada digester untuk menghindari kebocoran

5. Menempatkan semua digester ke dalam ruang dengan suhu $25^{\circ} \mathrm{C}-29^{\circ} \mathrm{C}$ yaitu suhu alami tanpa adanya perlakukan terhadap suhu.

Tabel 1. Perbandingan variasi komposisi limbah cair aren dengan kotoran sapi dalam tiap digester

\begin{tabular}{cccc}
\hline No & Nama campuran & $\begin{array}{c}\text { Limbah cair } \\
\text { aren }\end{array}$ & $\begin{array}{c}\text { Kotoran } \\
\text { sapi }\end{array}$ \\
\hline 1 & A : (digester A) & 1 & 0,25 \\
2 & B: (digester B) & 1 & 0,5 \\
3 & C: (digester C) & 1 & 0,75 \\
4 & D: (digester B) & 1 & 1 \\
5 & E: (digester C) & 1 & 1,25 \\
\hline
\end{tabular}


Tabel 2. Komposisi lengkap campuran bahan dalam tiap digester

\begin{tabular}{lcrrrr}
\hline No & Digester & $\begin{array}{c}\text { Limbah } \\
\text { cair } \\
\text { aren } \\
\text { (liter) }\end{array}$ & $\begin{array}{c}\text { Kotoran } \\
\text { sapi } \\
\text { (liter) }\end{array}$ & $\begin{array}{c}\text { Air } \\
\text { (liter) }\end{array}$ & $\begin{array}{c}\text { Jumlah } \\
\text { (liter) }\end{array}$ \\
\hline 1 & A & 8.8 & 2.2 & 3 & 14 \\
2 & B & 7.3 & 3.7 & 3 & 14 \\
3 & C & 6.3 & 4.7 & 3 & 14 \\
4 & D & 5.5 & 5.5 & 3 & 14 \\
5 & E & 4.9 & 6.1 & 3 & 14 \\
\hline
\end{tabular}

\subsubsection{Pengukuran $\mathrm{pH}$ pada digester}

1. Pengukuran $\mathrm{pH}$ pada digester dilakukan pada hari pertama sebagai data awal. Selanjutnya pada hari ke 10 dan setiap 9 hari hingga hari ke 42 setiap pengujian gas metan.

2. Pengukuran $\mathrm{pH}$ dilakukan dengan menggunakan $\mathrm{pH}$ universal dan $\mathrm{pH}$ meter dengan cara mengambil sampel melalui sumbat karet kecil pada digester dengan menggunakan jarum suntik.

\subsubsection{Pengujian Suhu}

Pengukuran suhu dilakukan mulai hari ke pertama kemudian hari ke 10 dan setiap 9 hari sampai hari ke 42 . Pengukuran suhu ini dilakukan dengan cara mengamati termometer yang ada pada digester.

\subsubsection{Pengukuran Volume Biogas}

Pengukuran volume biogas melalui tahapan sebagai berikut

1. Volume gas diambil mulai hari ke 5 dan selanjutnya diukur setiap hari untuk menghindari tekanan gas yang berlebihan.

2. Volume biogas diukur dengan menggunakan gas holder (120 cm setara dengan 1 liter). Volume ini diambil melalui kran dengan cara membuka kran pada digester.

3. Volume biogas yang ditampung dilakukan uji nyala untuk melihat potensi gas yang mulai terbakar

\subsubsection{Pengujian Gas Metana}

Pengujian gas metan dilakukan dengan tahapan sebagai berikut :

1. Pengujian gas metan dilakukan mulai hari ke 10 dan setiap 9 hari sampai hari ke 42 .

2. Pengambilan sampel dilakukan dengan menggunakan jarum suntik dan dimasukkan ke dalam venoject.

3. Gas yang dihasilkan dilakukan pengujian kadar gas metan dengan menggunakan Gas Chromatography $\left(\mathrm{CH}_{4}\right.$ di laboratorium instrument teknik kimia UGM).

\section{Hasil dan Pembahasan}

\subsection{Karakteristik Limbah Cair Aren dan Kotoran Sapi}

Karakteristik limbah cair aren memiliki rasio $\mathrm{C} / \mathrm{N}$ sebesar 15 dan kotoran sapi sebesar 24 seperti pada Tabel 3. Dengan pencampuran kedua bahan tersebut diperoleh rasio $\mathrm{C} / \mathrm{N}$ dari 17-20, sehingga kondisi tersebut memenuhi karakteristik bahan baku dalam pembuatan biogas. Untuk menghitung rasio $\mathrm{C} / \mathrm{N}$ campuran bahan dengan menggunakan rumus :

$$
\text { rasio } \frac{C}{N}=\frac{\left(C N_{1} X M_{1}\right)+\left(C N_{2} X 2\right)}{M_{1}+M_{2}} \text {. }
$$

Dimana :

$$
\begin{aligned}
& C N_{1}=\frac{C}{N} \text { rasio bahan } 1, C N_{2}=\frac{C}{N} \text { rasio bahan } 2 \\
& M_{1}=\text { massa bahan } 1, M_{2}=\text { massa bahan } 2
\end{aligned}
$$

Tabel 3. Karateristik Limbah Cair Aren dan Kotoran Sapi

\begin{tabular}{rlrr}
\hline No & Parameter & $\begin{array}{c}\text { Limbah } \\
\text { Cair Aren }\end{array}$ & $\begin{array}{c}\text { Kotoran } \\
\text { Sapi }\end{array}$ \\
\hline 1 & pH & 4,34 & 9,83 \\
2 & Rasio C/N & 15 & 24 \\
& DM (Dry & $1,73 \%$ & $20.10 \%$ \\
3 & Matter $)$ & $45,34 \%$ & $86,78 \%$ \\
\hline \multicolumn{4}{r}{ Sumber : Hasil Pengujian, 2011 }
\end{tabular}

\subsection{Komposisi Campuran Limbah Cair Aren dan} Kotoran Sapi.

Pada penelitian ini banyak faktor yang mempengaruhi proses produksi biogas diantaranya adalah $\mathrm{C} / \mathrm{N}$ rasio. Nilai rasio $\mathrm{C} / \mathrm{N}$ sampel pada penelitian ini setelah dihitung adalah seperti pada Tabel 4 .

Tabel 4. Rasio C/N Komposisi Kotoran Sapi dan Limbah

\begin{tabular}{ccccccc}
\multicolumn{7}{c}{ Cair Aren } \\
$\begin{array}{l}\text { Digest } \\
\text { er }\end{array}$ & $\begin{array}{c}\text { Limbah } \\
\text { Cair } \\
\text { Aren }\end{array}$ & $\begin{array}{c}\text { Kotoran } \\
\text { Sapi }\end{array}$ & $\begin{array}{c}\text { Limbah } \\
\text { Cair } \\
\text { Aren } \\
(\mathbf{L})\end{array}$ & $\begin{array}{c}\text { Kotoran } \\
\text { Sapi (L) }\end{array}$ & $\begin{array}{c}\text { Air } \\
(\mathbf{L})\end{array}$ & $\begin{array}{c}\text { C/N } \\
\text { rasio }\end{array}$ \\
\hline A & $80 \%$ & $20 \%$ & 8,8 & 2,2 & 3,0 & 16,80 \\
B & $67 \%$ & $33 \%$ & 7,3 & 3,7 & 3,0 & 18,00 \\
C & $57 \%$ & $43 \%$ & 6,3 & 4,7 & 3,0 & 18,86 \\
D & $50 \%$ & $50 \%$ & 5,5 & 5,5 & 3,0 & 19,50 \\
E & $44 \%$ & $56 \%$ & 4,9 & 6,1 & 3,0 & 20,00 \\
\hline
\end{tabular}

Sumber : Hasil Pengujian, 2011

Tabel 4 menunjukkan rentang hasil perhitungan rasio $\mathrm{C} / \mathrm{N}$ campuran antara limbah cair aren dan kotoran sapi. Nilai rasio $\mathrm{C} / \mathrm{N}$ yang diperoleh sangat bervariasi antara komposisi yang satu dengan lain. Pada proses produksi biogas memiliki rasio $\mathrm{C} / \mathrm{N}$ yang optimal adalah sekitar 2030 (Nijaguna, 2006), tetapi dalam penelitian ini nilai rasio $\mathrm{C} / \mathrm{N}$ sampel sangat bervariasi, yang berkisar antara 17-20, dan semua komposisi termasuk dalam nilai rasio $\mathrm{C} / \mathrm{N}$ optimal. Penelitian ini tidak mengkondisikan nilai rasio $\mathrm{C} / \mathrm{N}$ karena ingin mengetahui pengaruh rasio $\mathrm{C} / \mathrm{N}$ dalam 
pembentukan biogas yang dihasilkan dari limbah cair aren dan kotoran sapi.

\subsection{Produksi Biogas Campuran Limbah Cair Aren dan Kotoran Sapi}

Produksi biogas yang tertinggi pada digester E yang memiliki perbandingan campuran $1: 1,25$ atau $44 \%: 56 \%$ dimana kotoran sapi lebih besar dari limbah cair aren (Tabel 5).

Tabel 5. Hasil Pengamatan Biogas dari Limbah Cair Aren dan Kotoran Sapi

\begin{tabular}{|c|c|c|c|c|c|c|}
\hline No & $\begin{array}{c}\text { Hari } \\
\text { ke }\end{array}$ & Digester & pH & Suhu & $\begin{array}{l}\text { Volume } \\
\text { gas (liter) }\end{array}$ & $\begin{array}{c}\text { Gas } \\
\text { Metan } \\
\text { (CH4) } \\
\% \\
\end{array}$ \\
\hline \multirow{5}{*}{1} & \multirow{5}{*}{0} & A & 6 & 27 & - & - \\
\hline & & B & 6.5 & 27 & - & - \\
\hline & & $\mathrm{C}$ & 6.8 & 28 & - & - \\
\hline & & $\mathrm{D}$ & 7 & 28 & - & - \\
\hline & & $\mathrm{E}$ & 7 & 29 & - & - \\
\hline \multirow{5}{*}{2} & \multirow{5}{*}{10} & A & 6.8 & 27 & 66.67 & 0.023 \\
\hline & & B & 7 & 27 & 75.00 & 0.43 \\
\hline & & $\mathrm{C}$ & 7 & 28 & 250.00 & 0.23 \\
\hline & & $\mathrm{D}$ & 7 & 28 & 66.67 & 7.7 \\
\hline & & $\mathrm{E}$ & 7,5 & 29 & 483.33 & 14.7 \\
\hline \multirow{5}{*}{3} & \multirow{5}{*}{18} & A & 7 & 28 & 41.67 & 1.36 \\
\hline & & B & 7 & 28 & 50.00 & 1.28 \\
\hline & & $\mathrm{C}$ & 7 & 29 & 83.33 & 1.27 \\
\hline & & $\mathrm{D}$ & 7.5 & 29 & 216.67 & 5.01 \\
\hline & & E & 7.7 & 30 & 250.00 & 8.9 \\
\hline \multirow{5}{*}{4} & \multirow{5}{*}{26} & A & 7 & 29 & 91.67 & 1.87 \\
\hline & & B & 7 & 29 & 125.00 & 4.25 \\
\hline & & $\mathrm{C}$ & 7 & 30 & 133.33 & 5.67 \\
\hline & & $\mathrm{D}$ & 7.5 & 30 & 316.67 & 9.56 \\
\hline & & E & 7.7 & 31 & 1558.33 & 16.76 \\
\hline \multirow{5}{*}{5} & \multirow{5}{*}{34} & A & 7 & 28 & 33.33 & 3.44 \\
\hline & & B & 7 & 28 & 41.67 & 7.36 \\
\hline & & $\mathrm{C}$ & 7 & 29 & 66.67 & 9.49 \\
\hline & & $\mathrm{D}$ & 7.7 & 29 & 75.00 & 13.32 \\
\hline & & $\mathrm{E}$ & 7.8 & 30 & 900.00 & 39.39 \\
\hline \multirow{5}{*}{6} & \multirow{5}{*}{42} & A & 7.01 & 28 & 25.00 & - \\
\hline & & B & 7.22 & 28 & 33.33 & 0.53 \\
\hline & & $\mathrm{C}$ & 7.31 & 28 & 41.67 & 3.17 \\
\hline & & $\mathrm{D}$ & 7.88 & 28 & 58.33 & 33.43 \\
\hline & & $\mathrm{E}$ & 8.21 & 30 & 2325.00 & 42,58 \\
\hline
\end{tabular}

Gambar 2 menunjukkan volume biogas yang dihasilkan pada digester E memiliki jumlah yang sangat besar mencapai 6,8 liter pada titik optimum dibandingkan dengan digester lainnya yang tidak mencapai 1 liter pada titik optimumnya. Digester D dengan perbandingan campuran yang sama antara kotoran sapi dengan limbah cair aren yaitu $1: 1$ menghasilkan produksi biogas yang lebih besar dari digester $\mathrm{A}, \mathrm{B}$ dan $\mathrm{C}$. Pada digester tersebut komposisi kotoran sapi sedikit sehingga volume biogas yang dihasilkan rendah. Hal ini disebabkan karena jumlah rasio $\mathrm{C} / \mathrm{N}$ pada komposisi pencampuran tersebut belum mencapai nilai optimal yaitu sebesar 16 .

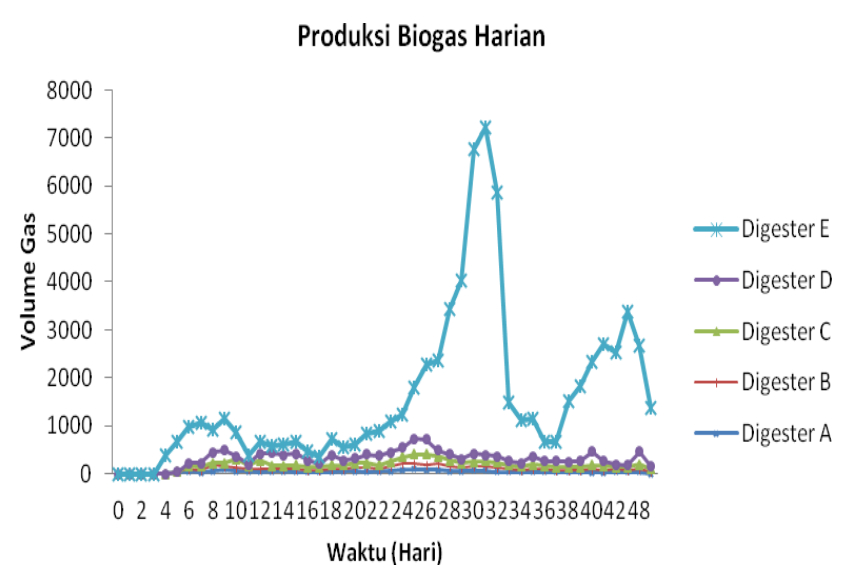

Gambar 2. Produksi biogas harian seluruh digester

\subsection{Kadar Gas Metan}

Kadar gas metan yang dihasilkan membentuk peningkatan yang linear dari digester A sampai digester E, dimana komposisi tersebut diberi kotoran sapi $25 \%$ hingga $125 \%$ dari digester A sampai digester $\mathrm{E}$.

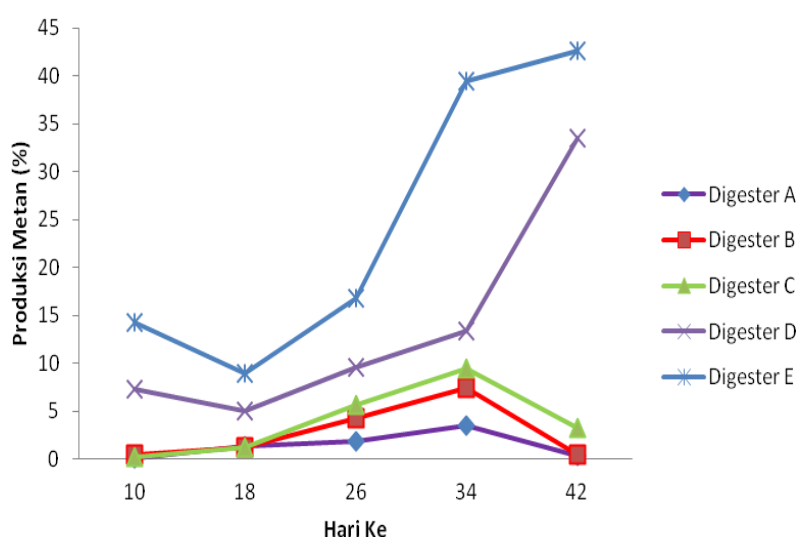

Gambar 3. Kadar Gas Metan seluruh digester

Gambar 3 menunjukkan kadar metan yang dihasilkan pada digester A paling sedikit yaitu hanya mencapai 3,44\% pada titik optimum dan dilakukan uji nyala belum menghasilkan api biru. Kadar gas metan pada seluruh digester mengalami pada minggu ke 2 sampai ke 3 yaitu dimulai 
hari ke 26 hingga hari ke 34. Pada digester A, B dan C mengalami penurunan pada hari ke 42, karena komposisi pada digester tersebut lebih banyak mengandung limbah cair aren dari pada kotoran sapi sehingga bakteri yang terdapat pada limbah tersebut sangat sedikit. Selain itu terjadinya regenerasi bakteri dari 5-16 hari. Pada digester D dan E dimana lebih banyak mengandung kotoran sapi mengalami peningkatan gas metan sampai hari ke 42. Hal ini disebabkan karena terjadi pembentukan metanogen, dimana masih terdapat bakteri yang bertahan sehingga metan yang terbentuk lebih tinggi. Dilihat dari rasio $\mathrm{C} / \mathrm{N}$ pada digester $\mathrm{D}$ dan $\mathrm{E}$ telah mencapai nilai optimal diperoleh rasio $\mathrm{C} / \mathrm{N}$ sebesar 20 .

\subsection{Pengamatan $\mathrm{pH}$}

Pengukuran $\mathrm{pH}$ pada penelitian ini menggunakan $\mathrm{pH}$ universal dan $\mathrm{pH}$ meter pada setiap pengambilan gas metan. Pengukuran $\mathrm{pH}$ dilakukan untuk mengetahui kadar keasaman campuran limbah dan perubahannya selama proses produksi biogas. $\mathrm{pH}$ sampel dari limbah cair aren tanpa kotoran sapi memiliki kadar asam yaitu 4,3 sedangkan kotoran sapi mempunyai $\mathrm{pH}$ alkali/basa yaitu 9,83 .

\section{Pengukuran pH pada Digester}

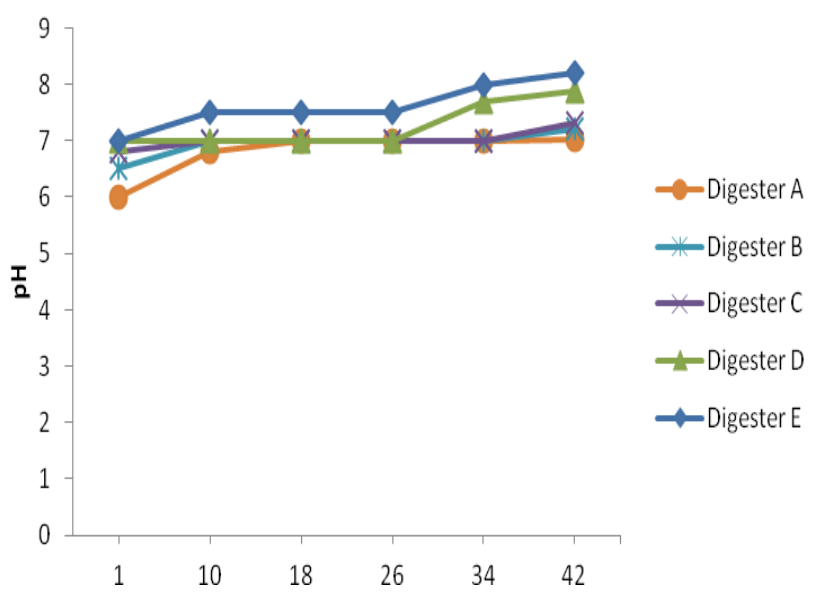

Gambar 4. Pengukuran $\mathrm{pH}$ pada digester

Pada pH sampel awal hari pertama, digester A - C memiliki $\mathrm{pH}$ yang masih asam karena campuran lebih didominasi oleh limbah cair aren yang bersifat asam (Gambar 4). Pada digester $\mathrm{D}$ dan $\mathrm{E}$ memiliki $\mathrm{pH}$ sampel normal yaitu 7 karena mengandung kotoran sapi yang lebih besar. Pada digester $\mathrm{A}, \mathrm{B}$ dan $\mathrm{C}$ dengan $\mathrm{pH} 6$ - 6,7 bakteri metanogen yang mampu bertahan untuk menghasilkan gas sangat sedikit karena kondisi keasaman substrat yang bisa membunuh bakteri, sehingga gas metana masih dihasilkan walaupun dalam jumlah sedikit. Setelah 10 hari $\mathrm{pH}$ semua sampel telah mencapai normal dari $\mathrm{pH}$ awal. Proses yang berlangsung mulai dari proses hidrolisis, asidogenesis, dan acetogenesis yang menghasilkan asam. Pada pengukuran hari ke 10 diindikasikan proses metanogenesis berlangsung dengan baik karena bakteri metanogen bisa beraktivitas menghasilkan metana pada pH 6,8 - 8,5 (Nijaguna, 2006).
Namun bakteri Methanosarcina bisa bertahan dengan kondisi $\mathrm{pH}=6,5$ (Deublin dan Steinhauser, 2008). $\mathrm{pH}$ dalam digester mengalami peningkatan hingga hari ke 42 . Pada digester D dan E berada pada suhu normal sehingga menghasilkan gas metan dan volume yang tinggi.

\subsection{Pengamatan Suhu}

Produksi gas berada pada kisaran mesofilik, antara suhu $25^{\circ} \mathrm{C}$ dan $30{ }^{\circ} \mathrm{C}$. Bakteri metanogen dalam keadaan tidak aktif pada kondisi suhu ekstrim tinggi maupun rendah. Pada penelitian ini pengukuran suhu dilakukan untuk memantau kondisi dalam digester. Suhu memiliki pengaruh pada proses pembentukan biogas. Suhu yang berada di dalam digester antara $27^{\circ} \mathrm{C}-31^{\circ} \mathrm{C}$ yaitu pada suhu mesofilik sehingga proses pembentukan metan dalam digester berlangsung dengan baik.

Pada masing-masing digester memiliki variasi suhu yang berbeda dan mengalami fluktuasi peningkatan maupun penurunan suhu. gambar 5 menunjukkan digester E dengan komposisi yang lebih banyak mengandung kotoran sapi memiliki variasi suhu yang tertinggi yaitu dari $29^{\circ} \mathrm{C}-31^{\circ} \mathrm{C}$. Sedangkan pada digester A dengan komposisi yang lebih banyak mengandung limbah cair aren memiliki variasi suhu yang terendah yaitu $27^{\circ} \mathrm{C}-29^{\circ} \mathrm{C}$

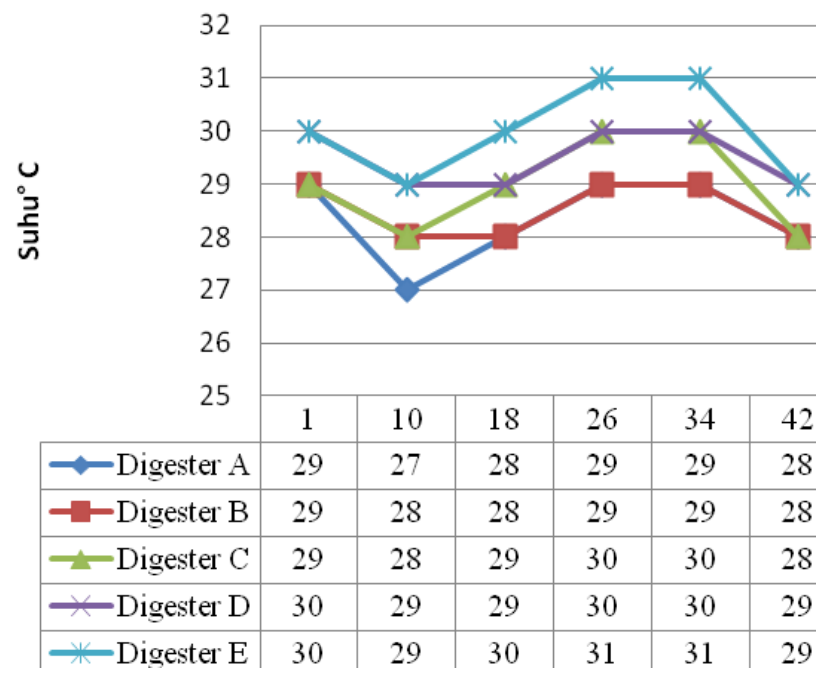

Gambar 5. Pengukuran Suhu pada digester

\section{Kesimpulan}

Dari analisis dan pembahasan diatas, dapat ditarik kesimpulan sebagai berikut :

1. Penambahan kotoran sapi pada limbah cair aren menghasilkan biogas dengan produksi yang tertinggi pada komposisi 56\% kotoran sapi dan 44\% limbah cair aren dengan rasio $\mathrm{C} / \mathrm{N}$ sebesar 20.

2. Produksi biogas dan kadar gas metan tertinggi tersebut dikarenakan kotoran sapi dapat menyeimbangi kandungan asam yang terkandung dalam limbah cair aren dan memprosesnya menjadi gas metan. Selain itu, dengan kandungan kotoran sapi yang lebih besar maka 
bakteri yang terdapat digester lebih banyak, sehingga pada saat fase metanogen bakteri yang bekerja masih bertahan dan menghasilkan gas metan dan volume yang besar.

3. Pada komposisi yang mengandung lebih banyak limbah cair aren menghasilkan produksi biogas dan kadar metan yang rendah, karena komposisi limbah cair aren masih dominan sehingga $\mathrm{pH}$ memiliki kandungan asam yang masih tinggi dan bakteri metan tidak dapat menyeimbangi pembentukan asam tersebut. Selain itu, rasio $\mathrm{C} / \mathrm{N}$ dari campuran komposisi tersebut hanya 17-19 sehingga produksi biogas dan gas metan yang dihasilkan tidak optimal.

4. Dalam penelitian yang dilakukan oleh Sapardi (2011) yaitu pembuatan biogas dari kotoran sapi dapat menghasilkan volume biogas tertinggi $55 \%$ dan gas metan $45 \%$, sementara penggunaan limbah cair aren dan kotoran sapi menghasilkan volume biogas tertinggi $48 \%$ dan gas metan $42 \%$. Namun dari hasil tersebut keuntungan yang diperoleh yaitu mengurangi penggunaan air dan kotoran sapi.

\section{Saran}

1. Pembuatan biogas dengan penambahan kotoran sapi pada limbah cair aren memiliki batas minimum kotoran sapi diatas $50 \%$ untuk dapat menghasilkan volume dan gas metan yang lebih tinggi. Pada penelitian ini tingkat pencampuran diperoleh 9,46\% dengan batas maksimum pencampuran $10 \%$.

2. Untuk mempercepat produksi biogas dan gas metan yang lebih tinggi dapat menambahkan inokulum dan rumen sapi yang dapat menambah kandungan bakteri pada limbah.

\section{Daftar Pustaka}

Deublin, D. dan A. Steinhauser, 2008, Biogas from Waste and Renewable Resources An Introduction, WileyVCH Verlag GmbH, Germany.

Irwanto, D., 2008, Analisis Kuantitatif Pengaruh Komposisi Umpan terhadap Kinerja Digester Kontinyu Horizontal untuk Produksi Biogas dari Kotoran Sapi, Teknik Kimia UGM, Yogyakarta

Nijaguna, B.T, 2006, Biogas Technology, New Age International Publisher, New Delhi.

Potter C, M. Soepardi, Alulia Gani, 1994, Limbah Cair berbagai Industri di Indonesia, Sumber pengendalian dan baku mutu, WMD Bappedal, Jakarta. 